\title{
RESPONS PERTUMBUHAN TANAMAN MENTIMUN (Cucumis sativus L.) TERHADAP PEMBERIAN KOMPOS FERMENTASI KOTORAN SAPI
}

\author{
Yuliana Mading $^{1 *}$, Dian Mutiara $^{2}$, Dewi Novianti $^{3}$ \\ ${ }^{1,2,3}$ Program Studi Biologi, Fakultas Sains dan Teknologi \\ Universitas PGRI Palembang \\ *e-mail: Yulianamading@yahoo.com
}

\begin{abstract}
Research on the Response of Cucumber (Cucumis sativus L.) Growth Response to Cow Manure Fermentation Compost has been conducted. The aim is to determine the response of cucumber plant growth to the provision of cow dung compost. Held in the Workshop of the Faculty of Mathematics and Natural Sciences, PGRI University Palembang in December 2019 to January 2020. using the experimental method in a completely randomized design (CRD), with 6 treatments 4 replications. The dosage of fertilizer used is P0 (without composting), P1 (200 grams of compost), P2 (300 grams of compost), P3 (400 grams of compost), P4 (500 grams of compost), P5 (600 grams of compost). The parameters observed included plant height $(\mathrm{cm})$, number of leaves (strands), stem diameter $(\mathrm{cm})$. The results showed that compost had a significant effect on the growth of plant height and number of leaves of cucumber plants, but had no significant effect on the stem diameter of cucumber plants and the best treatment on P5 (600 grams of compost) for all parameters.
\end{abstract}

Keywords: Cucumber (Cucumis sativus L.), Compost Fermented Cow Manure

\begin{abstract}
ABSTRAK
Telah dilakukan penelitian Respons Pertumbuhan Tanaman Mentimun (Cucumis sativus L.) Terhadap Pemberian Kompos Fermentasi Kotoran Sapi. Tujuan mengetahui respons pertumbuhan tanaman mentimun terhadap pemberian kompos kotoran sapi. Dilaksanakan di Workshop fakultas MIPA Universitas PGRI Palembang pada bulan Desember 2019 sampai Januari 2020. menggunakan metode eksperimen dalam rancangan acak lengkap (RAL), dengan 6 perlakuan 4 ulangan. Dosis pupuk yang digunakan adalah P0 (tanpa pemberian kompos), P1 (200 gram kompos), P2 (300 gram kompos), P3 (400 gram kompos), P4 (500 gram kompos), P5 (600 gram kompos). Parameter yang diamati meliputi tinggi tanaman $(\mathrm{cm})$, jumlah daun (helai), diameter batang $(\mathrm{cm})$. hasil penelitian menunjukan bahwa kompos berpengaruh nyata terhadap pertumbuhan tinggi tanaman dan jumlah daun tanaman mentimun, akan tetapi berpengaruh tidak nyata terhadap diameter batang tanaman mentimun dan perlakuan terbaik pada P5 ( 600 gram kompos ) untuk semua parameter.
\end{abstract}

Kata Kunci : Mentimun (Cucumis sativus L.), Kompos Fermentasi Kotoran Sapi 


\section{PENDAHULUAN}

Mentimun (Cucumis sativus L.) merupakan tanaman yang termasuk dalam familia Cucurbitaceae (tanaman labu-labuan), banyak dikonsumsi oleh masyarakat. Buahnya dapat dikonsumsi dalam bentuk segar, pencuci mulut, pelepas dahaga, untuk bahan kosmetik, dan dapat dijadikan bahan obat-obatan. Buah mentimun bisa digunakan sebagai bahan baku industri seperti minuman, permen dan parfum (Rukman 1994 dalam Abdurrazak, 2013).

Mentimun memiliki prospek yang baik untuk dibudidayakan dipasarkan baik di dalam negeri maupun di luar negeri. Berdasarkan data BPS (2016) produksi mentimun di Indonesia terus menerus menurun dari tahun ke tahun, pada tahun 2012 sampai tahun 2015 berturut-turut 511,525 ton/ha, 491,636 ton/ha, 477,976 ton/ha dan 447,677 ton/ha (Aeni, 2019).

Produktivitas mentimun sangat dipengaruhi oleh berbagai macam faktor yaitu seperti ketersediaan unsur hara makro dan mikro. Unsur hara yang dibutuhkan tanaman terdiri atas, Unsur hara makro adalah unsur hara yang dibutuhkan tanaman dalam jumlah banyak yaitu Nitrogen (N), Fosfor (P), Kalium (K), Kalsium (Ca), Magnesium $(\mathrm{Mg})$, dan Sulfur (S). Unsur hara mikro yang dibutuhkan tanaman dalam jumlah yang sedikit, tetapi harus selalu tersedia dalam jaringan tanaman, antara lain, Besi $(\mathrm{Fe})$, Mangan $(\mathrm{Mn})$, Tembaga $(\mathrm{Cu})$, Boron (Bo), Molibdenum (Mo), Klorida $(\mathrm{Cl})$, dan Seng (Zn) (Matana dan Masud, 2011).

Kompos merupakan hasil fermentasi oleh mikroorganisme yang menguraikan materi komplek menjadi unsur hara makro dan mikro Menurut (Dewi, 2012). Pengomposan adalah proses penguraian bahan-bahan organik secara biologis oleh mikroba-mikroba yang memanfaatkan bahan organik sebagai sumber energi. Proses pengomposan yang terjadi secara alami berlangsung lama dan lambat). (Dewi, 2012). Untuk mempercepat proses pengomposan dapat menggunakan larutan EM4. EM-4 merupakan larutan dapat mempercepat proses pengomposan, dan terbukti dapat menghilangkan bau yang timbul selama proses pengomposan berlangsung, tidak membahayakan lingkungan sekitar dan makluk lain. Larutan EM-4 juga dibuktikan secara ilmiah berperan mempercepat proses fermentasi limbah dan sampah organik, menekan pertumbuhan patogen tanah. Meningkatkan ketersediaan unsur hara dan senyawa organik pada tanaman, meningkatkan aktivitas mikroorganisme indogenus yang menguntungkan seperti Mycorrhiza sp., Rhizobium sp., dan bakteri pelarut fosfat, meningkatkan nitrogen, dan mengurangi kebutuhan pupuk dan pestisida kimia. Menurut Siswati $d k k$. , (2009).

Kotoran sapi adalah produk buangan dari saluran pencernaan hewan yang berupa feses yang mengandung nitrogen yang sangat tinggi, kotoran memiliki kandungan kimia berupa : Nitrogen 0,4- 1\%, Fosfor 0,2 -0,5\%, Kalium 0,1-1,5\%, Kadar Air 85,-92\% dan beberapa unsur hara lainya $(\mathrm{Ca}, \mathrm{Mg}, \mathrm{Mn}$, $\mathrm{Fe}, \mathrm{Cu}, \mathrm{Zn}$ ) (Dewi $d k k ., 2017$ ).

Kompos juga merupakan salah satu pupuk organik yang digunakan para pertanian untuk mengurangi penggunaan pupuk anorganik penggunaan pupuk kompos dapat memperbaiki sifat fisik tanah dan mikrobiologi tanah.kompos kotoran sapi mempunyai kadar serat yang cukup tinggi seperti selulosa, hal ini terbukti dari hasil pengukuran parameter $\mathrm{C} / \mathrm{N}$ rasio yang cukup tinggi $>40$. Disamping itu pupuk ini juga mengandung unsur hara makro seperti 0,5 $\mathrm{N}, 0,25 \mathrm{P} 2 \mathrm{O} 5,0,5 \% \mathrm{~K} 2 \mathrm{O}$ dengan kadar air $0,5 \%$, dan juga mengandung unsur mikro esensial lainnya (Irfan $d k k ., 2010$ ).

Manfaat dari kompos adalah meningkatkan kesuburan tanah, 
merangsang perakaran yang sehat, memperbaiki struktur tanah dengan meningkatkan kandungan bahan organik tanah, meningkatkan kemampuan tanah untuk mempertahankan kandungan air tanah. Aktivitas mikroba tanah yang bermanfaat bagi tanaman akan meningkat dengan penambahan kompos.

Berdasarkan uraian diatas maka telah dilakukan penelitian dengan tujuan untuk mengetahui respons pertumbuhan tanaman mentimu (Cucumis sativus L.) terhadap pemberian kompos fermentasi kotoran sapi.

Penelitian telah dilaksanakan pada bulan Desember 2019 sampai Januari 2020 di Workshop Fakultas MIPA Universitas PGRI Palembang. Adapun Alat dan Bahan yang digunakan timbangan, polybag ukuran $2 \mathrm{~kg}$, skop, kertas label, kamera, mistar, alat tulis, sedangkan Bahan yang digunakan dalam penelitian ini adalah: benih mentimun, tanah, air, kompos kotoran sapi.

Metode penelitan yaitu eksperimen dalam Rancangan AcakLengkap (RAL). Terdiri dari 6 perlakuan dan 4 ulangan.

$\mathrm{P}_{0}$ : kontrol (Tanpa pupuk kompos)

$\mathrm{P}_{1}: 200$ gram pupuk kompos/polybag

$\mathrm{P}_{2}: 300$ gram pupuk kompos/polybag

$\mathrm{P}_{3}: 400$ gram pupuk kompos/polybag

$\mathrm{P}_{4}: 500$ gram pupuk kompos/polybag

$\mathrm{P}_{5}: 600$ gram pupuk kompos/polybag

Data yang diperoleh dengan menggunakan analisis sidik ragam.Jika perlakuan berpengaruh nyata, maka dilanjutkan dengan uji lanjut BNT dengan membandingkan F-hitung dengan F-tabel Pada Q 5\%.

\section{HASIL DAN PEMBAHASAN}

\section{Respons Pertumbuhan Tanaman Mentimun Terhadap Pemberian Kompos.}

Hasil Ansira menunjukan bahwa pemberian kompos pada berbagi perlakuan berpengaruh sangat nyata terhadap tinggi tanaman mentimun sehingga dilakukan uji lanjut (tabel 1). Respons pemberian kompos terhadap pertumbuhan tinggi tanaman mentimun didapatkan rata-rata tinggi tanaman tertinggi pada perlakuan P5 (600 gram kompos $/ \mathrm{kg}$ tanah yang menghasilkan rata-rata tinggi tanaman mentimun $59,25 \mathrm{~cm}$,sedangkan hasil terendah pada perlakuan P0 (tanpa kompos) dengan rata-rata tertinggi tanaman $29,75 \mathrm{~cm}$.

\section{Respons Pertumbuhan Jumlah Daun Tanaman Mentimun Terhadap Pemberian Kompos.}

Hasil ansira menunjukan bahwa pemberian kompos pada berbagai perlakuan berpengaruh sangat nyata terhadap pertumbuhan jumlah daun tanaman mentimun (Tabel 2) Respons pertumbuhan rata-rata jumlah daun tanaman mentimun. terhadap pemberian kompos $/ \mathrm{kg}$ tanah) yang menghasilkan tertinggi terdapat pada perlakuan P5 (600 $\mathrm{g}$ kompos) menghasilkan rata-rata jumlah daun 15,5 helai, sedangkan hasil terendah terdapat pada perlakuan P0 (tanpa perlkuan) dengan rata-rata jumlah daun 8,75 helai.

\section{Respons Pertumbuhan Diameter Batang Tanaman Mentimun Terhadap Pembereian Kompos.}

Hasil ansira menunjukan bahwa pemberian kompos pada berbagai perlakuan berpengaruh tidak nyata terhadap diameter batang tanaman mentimun (Tabel 3) menunjukan bahwa hasil yang tertinggi pada pada diameter batang terdapat pada P5 $(600 \mathrm{~g}$ kompos/kg tanah) dengan rata-rata 0,59 $\mathrm{mm}$, sedangkan hasil terendah terdapat pada perlakuan P0 (tanpa kompos) dengan nilai rata-rata $0,34 \mathrm{~cm}$ 
Tabel 1. Respons Tanaman Mentimun (Cucumis sativus L.) terhadap pemberian kompos fermentasi kotoran sapi.

\begin{tabular}{ccc}
\hline Perlakuan & Rata-Rata Tinggi $(\mathbf{c m})$ \\
\hline P0 & 29,75 & $\mathrm{a}$ \\
P1 & 33,75 & $\mathrm{a}$ \\
P2 & 40,37 & $\mathrm{a}$ \\
P3 & 42,75 & $\mathrm{a}$ \\
P4 & 52,22 & $\mathrm{~b}$ \\
P5 & 59,25 & $\mathrm{~b}$ \\
\hline
\end{tabular}

$$
\text { BNT }_{0,05}=16,81
$$

Keterangan : Rata-rata dalam tabel yang diikuti oleh huruf yang sama artinya tidak berbeda nyata pada uji BNT 5\%

Tabel 2. Hasil uji BNT rata-rata jumlah daun tanaman mentimun (Cucumis sativus L)

\begin{tabular}{ccc}
\hline Perlakuan & Rata-Rata Jumlah Daun (Helai) \\
\hline P0 & 8,75 & $\mathrm{a}$ \\
P1 & 10,25 & $\mathrm{a}$ \\
P2 & 12,25 & $\mathrm{ab}$ \\
P3 & 12,75 & $\mathrm{ab}$ \\
P4 & 14 & $\mathrm{bc}$ \\
P5 & 15,5 & $\mathrm{bc}$ \\
\hline
\end{tabular}

\section{BNT $_{0,05}=2,30$}

Keterangan : Rata- Rata Dalam Tabel yang diikuti Oleh Huruf yang Sama Artinya Tidak Berbeda Nyata Pada Uji BNT 5\%.

Tabel 3. Hasil Analisis Sidik Ragam (ANSIRA) Respons Pertumbuhan Diameter Batang Tanaman Mentimun Terhadap Pemberian Kompos Fermentasi Kotoran Sapi:

\begin{tabular}{cccccc}
\hline $\begin{array}{c}\text { Sumber } \\
\text { Ragam }\end{array}$ & Db & Jk & Kt & Fhitung & Ftabel5\% \\
\hline Perlakuan & 5 & 0,16 & 0,03 & $0,06^{\text {tn }}$ & 2,77 \\
Galat & 18 & 0,01 & 0,5 & & \\
\hline Total & 23 & 0,17 & & & \\
\hline
\end{tabular}

Keterangan : Berpengaruh Tidak Nyata. 
Kompos merupakan unsur hara yang dibuat dari sisa-sisa tanaman atau kotoran hewan. Pupuk kompos berfungsi sebagai pemberi unsur hara dan untuk memperbaiki struktur tanah kandungan yang terdapatdalamkomposberupa Corganik, Nitrogen bagi tanaman yaitu untuk merangsang pertumbuhan secara keseluruhan, khusus batang cabang, dan daun, nitrogen juga berperan dalam pembentuk hijau daun yang sangat berguna dalam proses fotosintesis. Hal yang utama dari kotoran sapi adalah kandungan unsure haranya yang penting untuk tanaman adalah unsur Nitrogen $(\mathrm{N})$, fosfor $(\mathrm{P})$, dan kalium (K).

Pada tabel 1 diatas hasil uji BNT taraf 5\% dapat dilihat bahwa tanaman mentimun memberikan Respns berbeda tidak nyata terhadap pemberian kompos.

Berdasarkan hasi luji BNT 5\% dapat diketahui bahwa perlakuan P0 (tanpa kompos) berbeda nyata dengan perlakuan P5 (600 gram kompos), akan tetapi berbeda tidak nyata dengan perlakuan P1 (200 gram kompos) perlakuan P2 (300 gram kompos) perlakuan P3 (400 gram kompos), perlakuan P4 (500 gram kompos). Hal menunjukan bahwa perlakuan P5 memberikan hasil yang terbaik untuk parameter tinggi terhadap pertumbuhan tanaman mentimun yaitu dengan rata- rata $59,25 \mathrm{~cm}$. Pertumbuhan tinggi tanaman mentimun menunjukan laju pertumbuhan yang meningkat dari perlakuan P1, P2 , P3, P4dan P5. Pada dosis tersebut unsur hara makro $\mathrm{N}, \mathrm{P}$ dan $\mathrm{K}$ cukup tersedia sehingga dapat menstimulir pertumbuhan tanaman (Tetelay, 2018).

Pada Tabel 2 hasil uji BNT taraf $5 \%$ dapat dilihat bahwa tanaman mentimun memberikan respons berbeda nyata terhadap pemberian kompos yang diberikan. Berdasarkan uji BNT 5\% dapat diketahui bahwa perlakuan P0 tidak berbedanyata dengan perlakuan P1 (200 gram kompos ), perlakuan P2 ( 300 gram kompos), tidak berbedanyata dengan perlakuan P3 (400 gram kompos), sedangkan perlakuan P4 ( 500 gram kompos), berbedanyata dengan P5 ( 600 gram kompos). Hasiluji BNT tidak terjadi kenaikan yang signifikan dari P1, P2, P3, P4 dan P5 terhadap jumlah daun tanaman mentimun, tetapi secaras tatistic terjadi kenaikan jumlah daun tanaman mentimun seiring dengan peningkatan pemberian konsentrasi kompos kotoran sapi. Pramitasari dkk., (2016), menyatakan bahwa bila nitrogen diberikan dalam jumlah yang cukup pada tanaman, kebutuhan akan seperti fosfor meningkat untuk mengimbangi laju pertumbuhan tinggi, panjang daun tanaman denga ncepat, dimana ketersediaan unsur hara yang terdapat dalam kompos tidak lebih maupun kekurangan sehingga pertumbuhan tanaman lebih cepat dan optimal. Terjadinya peningkatan jumlah daun pada tanaman juga berhubungan dengan pertambahan tinggi tanaman. Apabila semakin tinggi batang tanaman, maka jumlah titik tumbuh daun akan semakin banyak, sehingga mengakibatkan jumlah daun bertambah banyak.

Berdasarkan hasil Analisis Sidik Ragam (ANSIRA) pada tabel 3 didapatka $\mathrm{n}$ hasil bahwa $\mathrm{F}_{\text {hitng }} 0,06<\mathrm{F}$ tabel 2,77 , yang artinya perlakuan pemberian kompos memberikan pengaruh tidaknyata terhadap pertumbuhan diameter batang tanaman mentimun. Pada tabel 3 diameter batang tanaman mentimun bahwa perlakuan P0 menghasilkan rata-rata $0,34 \mathrm{~cm}$, perlakuan P1 menghasilkan rata-rata $0,47 \mathrm{~cm}$ perlakuan P2 menghasilkan rata-rata $0,52 \mathrm{~cm}$, perlakuan $\mathrm{P} 30,42 \mathrm{~cm}$ perlakuan $\mathrm{P} 4$ menghasilkan rata-rata $0,51 \mathrm{~cm}$, perlakuan P5 menghasilkan rata-rata $0,59 \mathrm{~cm}$.Berdasarkannilai rata-rata terhadap masing-masing perlakuan pada diameter batang pemberian kompos memberikan hasil yang berbeda tidaknyata diantara setiap perlakuan, akan tetapi pada perlakuan P5 menunjukan nilai rata-rata tertinggi sedangkan P0, P1, P2, P3, P4 Menunjukan nilai terendah. Secaras tatistic 
pemberian kompos berpengaruh tidaknyata terhadap pertumbuhan diameter batang tanaman mentimun akan tetapi perlakuan P5 memberikan respons yang terbaik bila dibandingkan dengan perlakuan P0, perlakuan $\mathrm{P} 1$, perlakuan $\mathrm{P} 2$, perlakuan P4. Diameter batang tidak betambah besar karena tidak adanya pembelahan sel dikarenakan aktivitas meristem lateral dan kurangnya unsur hara fosfor, nitrogen, kalium yang diserap oleh tanaman. Pembelahan sel dapat menambah ukuran diameter organ. Fosfor adalah unsur hara yang terdapat pada nukleotida yang merupakan pembetuk asam nukleat. Nitrogen dan kalsium berpengaruh dalam pembentuk pertumbuhan diameter batang tanaman. Nitrogen adalah bagian dari protein dan protoplasma, enzim, katalis biologis yang berfungsi unut kmempercepat proses metabolisme. Sedangkan kalium berperan dalam membentuk protein, mengeraskan batang tanaman, meningkat ketahanan tanaman dari penyakit (Amalia, 2015). Penyerapan unsur hara oleh tanaman tidak secara lansung diserap sekaligus untuk pertumbuhan diameter batang, diawal penanaman unsur hara akan tertuju pada pertumbuhan tinggi tanaman dan saat mendekati akhir vegetative unsur hara akan diserap oleh diameter batang (Puspadewi dkk., 2016).

Tanah merupakan media unutuk bercocok tanam yang sangat berpengaruh terhadap kesuburan tanaman.Media tanam yang baik untuk mentimun adalah tanah gembur yang banyak mengandung humus. Budidaya mentimun menghendaki tanah yang memiliki tata air baik (irigasi) serta drainase yang baik pula. Tanaman mentimun membutuhkan tanah yang subur, gembur, banyak mengandung humus, tidak menggenang dan memiliki $\mathrm{pH} 6-7$ agar menghasilkan produksi yang tinggi dan kualitas yang baik(Umar Dani, 2014). Pupuk kompos merupakan unsur hara yang dibuat dari sisa-sisa tanaman atau kotoran hewan. Pupuk kompos berfungsi sebagai sumber unsur hara dan untuk berfungsi memperbaiki struktur tanah. Kotoran sapi dijadikan kompos karena memiliki kandungan kimia yang bisa membantuh memperbaiki struktur tanah dan memberi unsur hara ke tanaman yaitu: nitrogen 0,4$1 \%$, phospor $0,2-0,5 \%$, kalium $0,1-1,5 \%$, kadar air 85,-92\% dan beberapa unsur hara lainya (Ca, $\mathrm{Mg}, \mathrm{Mn}, \mathrm{Fe}, \mathrm{Cu}, \mathrm{Zn}$ ). (Dewi $d k k$., 2017).. kompos ketersediaan unsur hara yang dapat diserap oleh tanaman merupakan salah satu faktor yang dapat mempengaruhi tingkatan produktifitas suatu tanaman. Pada dasarnya jenisdan jumlah unsur hara yang tersedia di dalam tanah harus cukup dan seimbang untuk pertumbuhan agar tingkat produktifitas yang diharapkan ditercapai dengan baik. Pemberian kompos kotoran sapi pada tanaman mentimun cukup memperlihat respons yang baik, karena dapat meningkatkan pertumbuhan dan produksi metimun. Meskipun pertumbuhan tanaman mentimun kuarang normal akan tetapi kompos fermentasi kotora sapi mampu merespons pertumbuhan tanaman mentimun. cukup baik terutama pertumbuhan tinggi, jumlah daun tanaman dibandingkan dengan tanaman tanpa diberi perlakuan kompos. Hal ini menunjukan bahwa kompos kotoran sapi berpotensi digunakan sebagai bahan baku kompos.

Menurut Sryanto dkk., (2015) pengaru pemberian pupuk kandang sapi dengan dosis 7,26 gram memberikan berpengaruh sangat nyata terhadap pertumbuhanberat buah terung, panjang buah, jumlah buahpada tanaman terung (Solanum melongena.L.) pertumbuha tinggi tanaman merupakan pertumbuhan primer yang dipengaruhi oleh aktifitas sel meristem apikal yang memanjang dan membelah. Proses ini merupakan sintesa protein yang diperoleh tanaman dari lingkungan seperti bahan oraganik dalam tanah.Hasil penelitian Fefiani $d k k$.,(2014) pemberian pupuk kandang sapi terhadap pertumbuhan mentimun (Cucumis sativus L.) dengan dosis sebesar 7,2 kg/plot akan 
meningkatkan panjang tanaman sebesar 144,67 cm, jika dibandingkan dengan perlakuan tanpa pupuk kandang sapi.

\section{KESIMPULAN}

Dari ketiga parameter yang diamti terhadap Respons pertumbuhan tanaman mentimun terhadap pemberian kompos fermentasi kotoran sapi pada perlakaun P5 (600 gram) menghasilkan dengan nilai rata-rata pada pertumbuhan tinggi tanaman yaitu 59,25 cm, rata-rata tertinggi pada jumlah daun yaitu 15,5 helaidan rata-rata tertinggi pada diameter batang $0,59 \mathrm{~cm}$.

\section{DAFTAR PUSTAKA}

Abdurrazak, M. H, dan A. Marliah. 2017.Pertumbuhan dan Hasil Tanaman Mentimun (Cucumis sativus L.) Akibat Perbedaan Jarak Tanam dan Jumlah Benih Per Lubang Tanaman. Jurnal Agrista 17 (2) : 55-59 hlm.

Amalia,W.2015. Pemberian Fariasi Konsentrasi Pupuk Dari Limbah Cair Tahu Pertumbuhan Tanaman Cabi Rawit (Capsicum frutescens). skripsi. Universitas Islam Negeri Walisongo.

Aeni, S. N., Rini S., dan Pasetriyani. 2019. Pengaruh Pemangkasan Pucuk Terhadap Pertumbuhan dan Hasil Tanaman Mentimun Jepang (Cucumis sativus L.) diataran Tinggi Lembang. Jurnal Agroscience 9 ( 1) :26-33 hlm.

Dani, U. A Harti. ,D. Nugraha dan Rusta.2014.Pertumbuhan dan Hasil Tanaman Mentimun (Cucumis sativus L.) Kultivar Sabana F1 dan Vanesa pada Berbagai Dosis Pemberian Biofosfat.Jurnal Ilmu Pertanian dan Peternakan 2 (2) : 1- $8 \mathrm{hlm}$.

Dewi, Y.S., Treesnowati. 2012. Pengolahan Sampah Skala Rumah Tangga Menggunakan Metode
Composting. Jurnal Ilmiah 8 (2): 35$48 \mathrm{hlm}$.

Dewi, N. M. E. Y, dan Y., I .M. Nada. 2017. Pengaruh Bahan Tambahan Pada Kualitas Kompos Kotoran Sapi. Jurnal Beta (Biosistem dan Teknik Pertanian) Program Studi Teknik Pertanian, Fakultas Teknologi Pertanian. Universitas Udayana Http://Ojs.Unud. Ac. Id/Index. Php /Beta. 5 (1) : 76-82 hlm.

Fefiani,Yusari dan Wan A. Barus. 2014. Respon Pertumbuhan dan Produksi Tanaman Mentimun (Cucumis sativus L.) Akibat Pemberian Pupuk Kandang Sapi dan Pupuk Organik Padat Supernasa. Jurnal Agroekotek nologi 19(1) :21-30 hlm.

Irfan, R, dan D. Mahendra. 2010. Pengaruh Penambahan Bagasse (Ampas Tebu) dan Lama Fermentasi terhadap Mutu Bokasi. Jurnal Teknologi dan Industri Pertanian Indonesia 2 (2): 25-29 hlm.

Matana,Y dan M. Masud. 2015 Rrespon Pemupukan NPK dan Mg Terhadap Kandungan Unsur Hara Tanah dan Daun Pada Tanaman Muda Kelapa Sawit. Jurnal Penelitian Kelapa Sawit 12 (13): 23-31 hlm.

Puspadewi,S.,S.W.Sutari dan Kusumawati. 2016. Pengaruh Konsentrasi Pupuk Oraganik Cair (POC) dan Doais Pupuk N,P,K Terhadap Pertumbuhan dan Hasil Tanaman Jagung Manis (Zea mays L.). Jurnal kultivasi.15 (3):208-216 hlm.

Pramitasari, H. E., T. W. M. dan Nawawi. 2016. Pengaruh Dosi Pupuk Nitrogen dan Tingkat Kepadatan Tanaman Terhadap Pertumbuhan dan HasilTanaman Kailan (Brassica oleraceaeL.), Jurnal Produksi Tanaman, 4.( 1). $49-56 \mathrm{hml}$. 
Siswati, N. D., H. Theodorus dan P. W. Eko S. 2009. Kajian Penambahan Effective Microorganisms $\left(\mathrm{EM}_{4}\right)$ Pada Proses Dekomposisi Limbah Padat Industri Kertas. Jurnal Buana Sains 9(1): 63-68 hlm.

Tetelay, F. 2018. Penggunaan Pupuk Kandang (Kotoran Sapi) Pada Semai Tanaman Kehutanan, Jurusan Kehutanan Fakultas Pertanian Unpatti.Jurnal Makila 7(1) : 63$73 \mathrm{hlm}$.

Sriyanto, D., P. Astuti dan A.P. Sujalu. 2015. Pengaruh Dosis Pupuk Kandang Sapi Terhadap Pertumbuhan dan Hasil Tanaman Terung Ungu dan Terung Hijau (Solanum Melongena L.). Jurnal Agrifor 14(1) : 39-44 hlm. 